УДК 576.4

(C) 2017

Самойлік М. С., доктор економічних наук, професор кафедри

землеробства і агрохімії імені В. І. Сазанова

Полтавська державна аграрна академія

Молчанова А. В., аспірант

(науковий керівник - доктор економічних наук, професор кафедри землеробства і агрохімії імені В. І. Сазанова М. С. Самойлік)

\title{
АНАЛІЗ ФІТОТОКСИЧНОГО ЕФЕКТУ ФІЛЬТРАТУ, ГРУНТУ ТА ПИТНОЇ ВОДИ БІЛЯ ПОЛТАВСЬКОГО ПОЛІГОНУ ТПВ
}

\author{
Рецензент - професор кафедри землеробства і агрохімії ім. В. І. Сазанова, \\ доктор сільськогосподарських наук, професор, илен-кореспондент \\ інженерної академії Украӥни П. В. Писаренко
}

Внаслідок росту виробництва, спожсичої активності населення, нераціонального використання ресурсів, обмеженого залучення вторинних ресурсів у виробництво, відсутність дієвих організаційноекологічних механізмів стимулювання рецииркуляиіі відходів, проблема твердих побутових відходів набула глобального характеру. Полігони твердих побутових відходів - типовий приклад антропогенної діяльності. Для них характерні низка ознак хімічного забруднення трунтів, поверхневих, грунтових та підземних вод, рослинних груп, атмосферного повітря, які $\epsilon$ об'єктами різноманітних екологічних досліджень.

Ключові слова: ТПВ (тверді побутові відходи), вплив, аналіз, грунт, вода, фільтрат, полігон.

Постановка проблеми у загальному вигляді та її зв'язок із важливими науковими чи практичними завданнями. Сучасне поводження з відходами нераціональне, має результатом їх зростаюче накопичення і несумісне 3 державною концепцією сталого розвитку України. В Україні нараховується щонайменше 12538 звалищ, з яких 6690 несанкціоновані та 5317 невпорядковані. Проблема складування і зберігання відходів в даний час $\epsilon$ однією з найактуальніших і життєво важливих для України екологічних і економічних проблем. Полігони твердих побутових відходів істотно впливають на питну воду поблизу полігону та грунт.

Аналіз останніх досліджень і публікацій, у яких започатковано розв'язання проблеми. Фітотоксичний аналіз, де дослідні ділянки були закладені з грунту та зрошені фільтратом з полтавського полігону ТПВ і питною водою, відібраною поблизу полігону, ще не проводився. Загальні теоретично-методичні питання щодо екологічних аспектів вирішення народногосподарських проблем та ефективності природоохоронних заходів, пов'язаних 3 вирішенням проблем поводження з відходами, розроблялися в роботах Балацького О. Ф., Бистрякова І. К., Борщевського П. П., Буна Е., Дорогунцова С. І., Качинського А. Б., Лимаренка В. О., Міщенка В. С., Мельника Л. Г., Хенса Л., Шевчука В. Я. та інших. Значний вклад у розробку питань визначення екологічних пріоритетів природоохоронної діяльності під час поводження з відходами, у тому числі з ТПВ, а також у науково-методичне та нормативно-правове забезпечення відповідної діяльності, внесли своїми працями Вашкулат М. П., Вілсон Д., Горлицький Б. О., Дрейер А. А., Манелис Б. Г., Міщенко В. С., Маторін Є. І., Никольський К. С., Сігал І. Я., Столберг Ф. В. та інші, проте багато аспектів поводження $з$ відходами, в тому числі з ТПВ, залишаються недостатньо вирішеними.

Метою даної роботи є дослідження впливу полігонів твердих побутових відходів на навколишнє середовище через визначення впливу грунту, води та фільтрату на сходи, ріст та кореневу систему висадженого насіння за фітотоксичного аналізу. Метод визначення фітотоксичності грунту заснований на здатності насіння озимої пшениці реагувати на наявність забруднення у грунтовому та водному середовищі, в якому пророщують насіння.

Методи досліджень: польовий, методи математичної статистики, економічна оцінка.

Предмет досліджень - процеси, що відбуваються під час росту висадження насіння в різних видах грунту під дією різних рідин поливу. Вплив полігону ТПВ на сходи, ріст та кореневу систему.

Практична значимість. Проведене дослідження є комплексним аналізом впливу функціонуючого полтавського полігону ТПВ на сходи, ріст та кореневу систему висадженого насіння озимої пшениці. Саме такий аналіз із викорис- 


\section{СІЛЬСЬКЕ ГОСПОДАРСТВО. РОСЛИННИЦТВО}

танням дослідних ділянок 3 полтавського полігону ТПВ ще не проводився, тому зроблений аналіз може бути використаний для розробки моделювання та прогнозування впливу цього об'єкту ТПВ на довкілля.

Результати досліджень. Проведений фітотоксичний аналіз впливу водного та грунтового середовища поблизу полтавського полігону ТПВ на сходи, ріст та кореневу систему озимої пшениці показав знижені показники всходження, росту та кореневої системи у всіх трьох критеріях під дією фільтрату, питної води та грунту поблизу полігону ТПВ. Здійснено обрахунок фітотоксичного ефекту щодо довжини кореневої системи, довжини рослин, кількості взійдених рослин.

19.10.2017 року насіння озимої пшениці сорту «Зелений гай» (по 100 шт) були висаджені в окремі посудини в різні види грунтів. Були закладені 8 дослідних ділянок. 3 трикратним повторенням. 3 використанням такого грунту та зрошення як:

1. чистого грунту та чистої води;

2. чистого грунту та води поблизу полігону ТПВ;

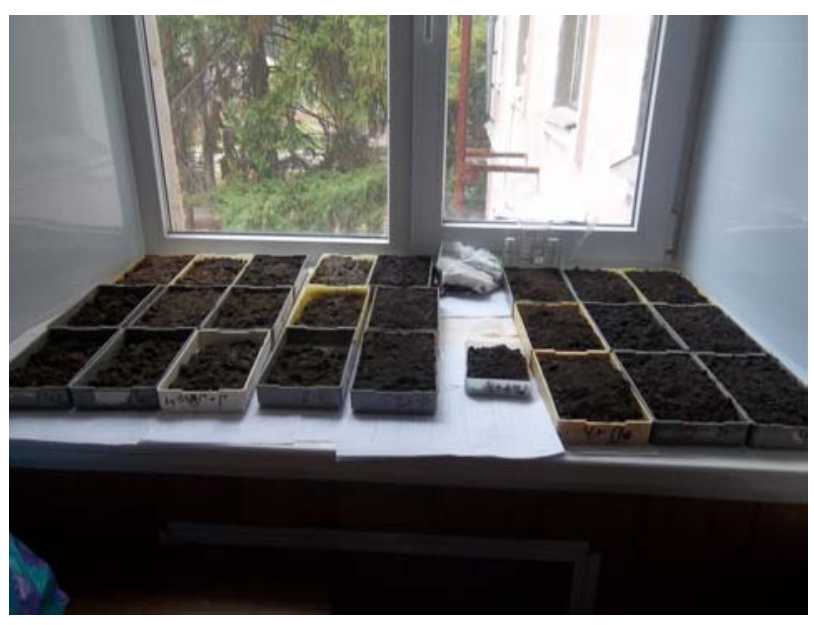

3. чистого грунту та пребіотику;

4. чистого грунту та фільтрату з полігону;

5. грунту з полігону ТПВ та фільтрату 3 полігону;

6. грунту з полігону ТПВ та води поблизу ТПВ;

7. грунту з полігону ТПВ та пребіотику;

8. грунту з полігону ТПВ та чистої води.

Де чистий грунт був набраний у селі Бречківка Полтавської області (як контрольний зразок для порівняння). Грунт із полігону ТПВ був набраний поруч $з$ полтавським полігоном ТПВ зі сторони села Макухівка. Вода поблизу полігону ТПВ була набрана в с. Макухівка, за 350-400 метрів від полігону ТПВ у колонці на вул. Озерній. Чиста вода була набрана дистильована вода (як контрольний зразок для порівняння).

Перші сходи були 23.10.2017 року із дослідної ділянки №1 (де чистий грунт та чиста вода), до 26.10.2017 року паростки проросли до довжини 1,5-2 см. Дружні сходи. На дослідних ділянках № 2 и 3 посіви лише почали сходити, а на інших дослідних ділянках паростків немає.

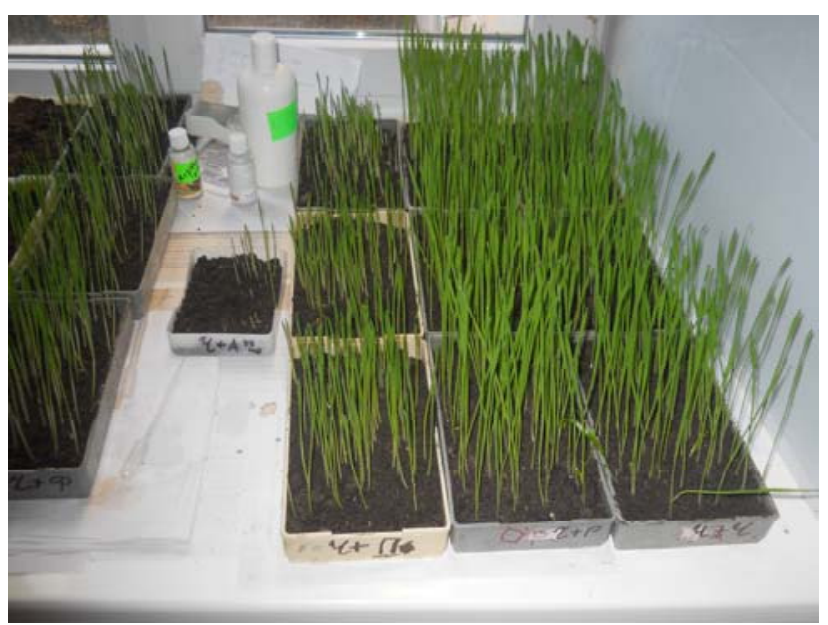

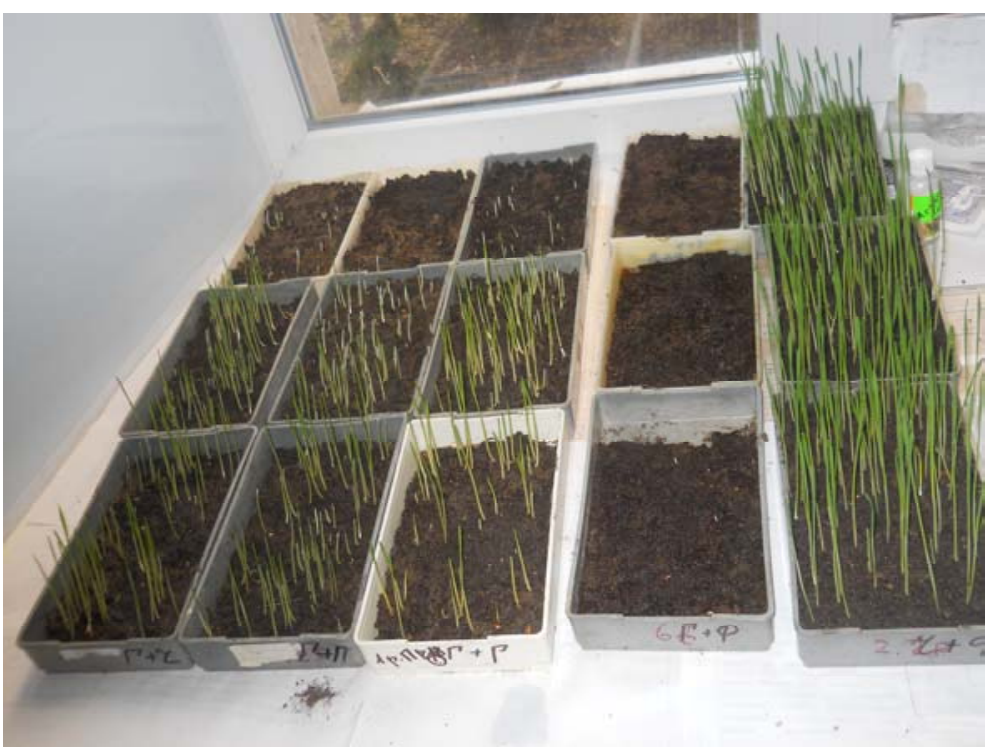




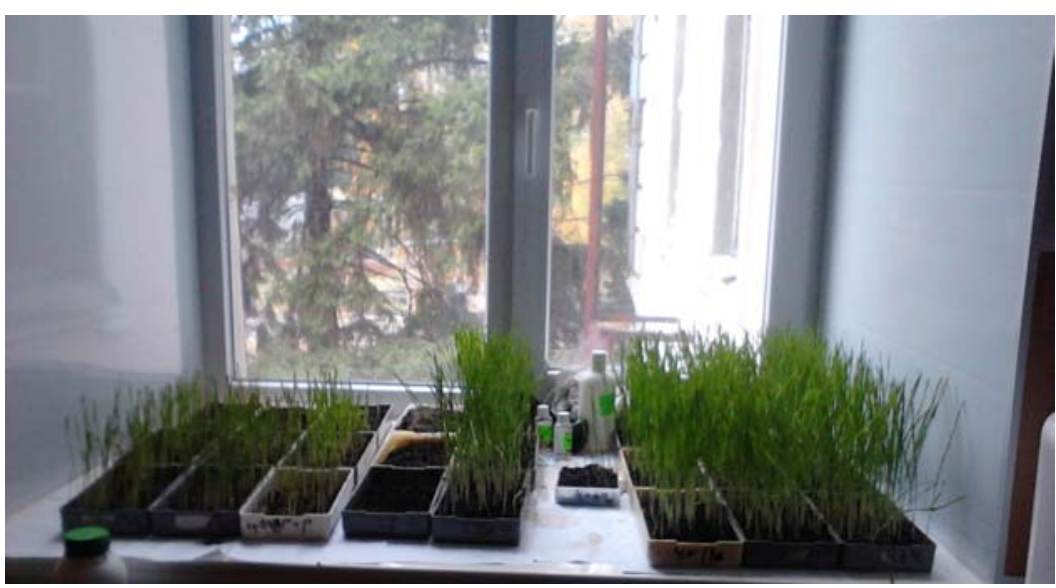

Станом на 07.11.2017 року дослідні ділянки мали такий вигляд

Станом на 01.11.2017 року посіви озимої пшениці в чистому грунті, які зрошувалися чистою водою, та посіви в чистому грунті, які зрошувалися водою з колонки с. Макухівка отримали дружні та рівні сходи, вони мали яскравозелений колір і виглядали здоровими. Посіви в чистому грунті, які зрошувалися фільтратом дещо відставали у рості, але також досить дружно зійшли. В грунті 3 полігону ТПВ у кожному 3 двох повторень, які окремо зрошували чистою водою, водою $з$ криниці отримали пізні дуже зріджені, дещо пригнічені і нерівномірні сходи.

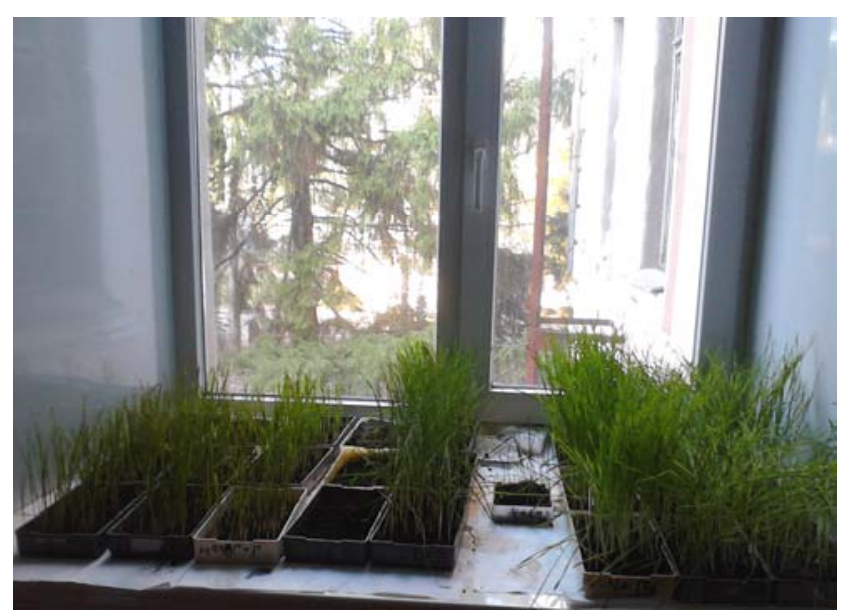

У третіх повтореннях кожного зі зразків сходів майже немає. I в усіх трьох повтореннях у зразках $з$ грунтом 3 полігону ТПВ, які зрошувалися фільтратом, - сходів не отримали.

Дослід проводився 30 діб, після чого визначали частку пророслих насінин, і виміряли довжину проростання. За отриманими даними вираховували кількість сходів, ріст насіння та кореневу систему в порівнянні 3 контролем. Дослід було закінчено 17.11.2017 року. Результати сходів висвітлені у таблиці 1, ріст насіння у таблиці 2 . Дослідні ділянки мали такий вигляд

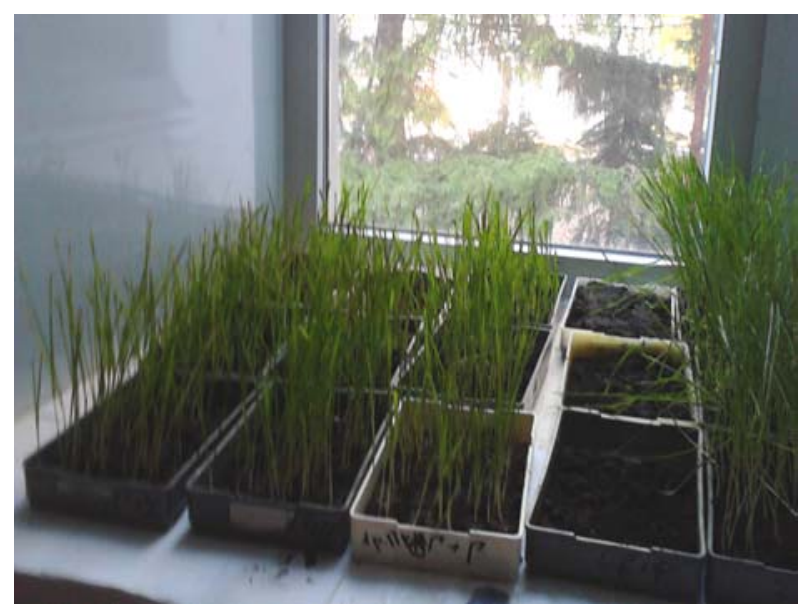

Таблиия 1

\begin{tabular}{|l|c|c|c|c|c|c|}
\hline & $\begin{array}{c}\text { Чистий } \\
\text { грунт та } \\
\text { чиста вода }\end{array}$ & $\begin{array}{c}\text { Чистий грунт } \\
\text { та вода побли- } \\
\text { зу полігону } \\
\text { ТПВ }\end{array}$ & $\begin{array}{c}\text { Чистий } \\
\text { грунт та } \\
\text { фільтрат 3 } \\
\text { полігону }\end{array}$ & $\begin{array}{c}\text { Ірунт 3 полі- } \\
\text { гону ТПВ та } \\
\text { фільтрат 3 } \\
\text { полігону }\end{array}$ & $\begin{array}{c}\text { Ірунт 3 полі- } \\
\text { гону ТПВ та } \\
\text { вода поблизу } \\
\text { ТПВ }\end{array}$ & $\begin{array}{c}\text { Грунт 3 полі- } \\
\text { гону ТПВ та } \\
\text { чиста вода }\end{array}$ \\
\hline $\begin{array}{l}\text { Перша дослідна } \\
\text { ділянка }\end{array}$ & 96 & 88 & 70 & 1 & 73 & 86 \\
\hline $\begin{array}{l}\text { Друга дослідна } \\
\text { ділянка }\end{array}$ & 94 & 91 & 61 & 1 & 84 & 89 \\
\hline $\begin{array}{l}\text { Третя дослідна } \\
\text { ділянка }\end{array}$ & 100 & 80 & 65 & 0 & 81 & 81 \\
\hline $\begin{array}{l}\text { Середній пока- } \\
\text { зник }\end{array}$ & $96,6(6)$ & $86,3(3)$ & $65,3(3)$ & $0,6(6)$ & $79,3(3)$ & $85,3(3)$ \\
\hline
\end{tabular}




\begin{tabular}{|l|c|c|c|c|c|c|}
\hline & $\begin{array}{c}\text { Чистий } \\
\text { грунт та } \\
\text { чиста вода }\end{array}$ & $\begin{array}{c}\text { Чистий } \\
\text { грунт та во- } \\
\text { да поблизу } \\
\text { полігону } \\
\text { ТПВ }\end{array}$ & $\begin{array}{c}\text { Чистий } \\
\text { грунт та } \\
\text { фільтрат 3 } \\
\text { полігону }\end{array}$ & $\begin{array}{c}\text { Грунт 3 полі- } \\
\text { гону ТПВ та } \\
\text { фільтрат 3 } \\
\text { полігону }\end{array}$ & $\begin{array}{c}\text { Грунт 3 по- } \\
\text { лігону ТПВ } \\
\text { та вода по- } \\
\text { близу ТПВ }\end{array}$ & $\begin{array}{c}\text { Грунт 3 по- } \\
\text { лігону ТПВ } \\
\text { та чиста } \\
\text { вода }\end{array}$ \\
\hline $\begin{array}{l}\text { Висота рос- } \\
\text { ту (см) }\end{array}$ & $29-33$ & $25-28$ & $15-18$ & $3-4$ & $8-14$ & $14-20$ \\
\hline
\end{tabular}

Таким чином, найбільшого впливу зазнала 5та дослідна ділянка. Насіння, висаджене у грунт 3 полігону ТПВ та зрошуване у фільтраті проростання насіння майже не дало, що характеризується максимальною токсичністю водного середовища (фільтрату) та вказує на наявність забруднюючих важких металів і їх перевищення ГДК.

На всіх дослідних ділянках, де був чистий грунт, добре розвинена коренева система і паростки сильні, на дослідних ділянках 3 грунтом iз полігону ТПВ - слабо розвинена коренева система і паростки слабкі та пригнічені.

Висновки 3 даного дослідження і перспективи подальших розвідок у даному напрямі. Проаналізувавши можна зробити висновки про істотний вплив полтавського полігону ТПВ на навколишнє середовище, а саме вплив на грунт поблизу полігону та питну воду, навіть у колонці на відстані 400 метрів від полігону.

За результатами проведених досліджень бачимо, що під впливом полігонів твердих побутових відходів, на прикладі полтавського полігону ТПВ, відбувається зараження підземних та поверхневих вод та грунту. Забруднені фільтратом грунтові води, що течуть до річки Коломак, $є$ серйозним, постійно діючим, багатокомпонент-

\section{БІБЛІОГРАФІЯ}

1. Бирюков Д. Б. Комплексный подход к решению проблемы утилизации твердых бытовых отходов / Д. Б. Бирюков, А. 3. Рыжавский, П. В. Богомаз, А. В. Томах // Экология и промышленность. - 2012. - №1. - С. 84-88.

2. Вашкулат М. П. Поводження з побутовими і сільськогосподарськими відходами 3 позицій санітарних вимог / М. П. Вашкулат, А. І. Костенко // Довкілля і здоров’я. - 2001. - №4. - С. 1011.

3. Губанова E. P. Глобализационный аспект проблемы твердых отходов / Е. Р. Губанова // Журнал «Экология плюс», 2009. - №1. - С. 27-29. ним джерелом забруднення, вплив якого необхідно ліквідувати або мінімізувати. Насіння, висаджене у грунт з полігону ТПВ та зрошуване у фільтраті проростання, насіння майже не дало, що характеризується максимальною токсичністю водного середовища (фільтрату) та вказує на наявність забруднюючих важких металів і їх перевищення ГДК. I насіння висаджене на дослідних ділянках на грунті з полігону ТПВ у порівнянні з контрольними зразками, де насіння висаджене у чистий грунт, показали гірші результати. Під впливом полігонів твердих побутових відходів відбувається забруднення грунту продуктами вилуговування, виділення неприємного запаху, розкид відходів вітром, мимовільне спалахування полігонів, безконтрольне утворення метану та неестетичний вигляд є лише часткою проблеми, яка турбує екологів та визиває серйозну незгоду 3 боку місцевих мешканців. Тверді побутові відходи несуть значну санітарну небезпеку, тому що є сприятливим середовищем для розвитку паразитичної фауни, патогенної мікрофлори (черевний тиф, дезентерія, туберкульоз та ін.), служать місцем розмноження переносників інфекційних захворювань: гризунів та мух.

4. Коныгин А. А. Очистка фильтрата полигонов захоронения твердых бытовых отходов / А. А. Коныгин, Л. С. Скворцов, А. Ф. Селиверстов // Водоснабжение и канализация. - 2010. №1-2. - С. 124-127.

5. Лабораторне дослідження, проведене в Полтавській державній аграрній академії 3 19.10.2017 по 17.11.2017 року.

6. Радовенчик В. М., Гомеля М. Д. Тверді відходи: збір, переробка, складування : навч. посіб. для студ. вищ. навч. закл. / В. М. Радовенчик, М. Д. Гомеля. - К. : Кондор, 2010. - 550 с. 